


\title{
Limits of VoC and institutional complementarities in the semi-periphery: comparative analysis of reforms in Brazil and India
}

\author{
Limites da VoC e complementariedade institu- \\ cional na semi-periferia: anćlise comparativa \\ das reformas de Brasil e Índia
}

* Carlos Henrique Vieira Santana

\begin{abstract}
In VoC theories, adopted in OECD countries, the state does not fulfill an important role in the productive system. On the other hand, by analyzing the trajectory of the semi-periphery countries, there is no way to describe the mechanisms of institutional complementarity without holding the state in the center of the model. That's the trajectories of Brazil and India. To evaluate the role of the state as a strategic actor in semiperipheral institutional complementarity this proposal suggests analyze the role of the state in the commanding heights of economic liberalization. In particular, the role of public banks and pension funds as anti-cyclical and coordinators actors of the new corporate ownership restructuring and external insertion adopted by large conglomerates in Brasil and India in the past ten years. Understanding this is crucial to point out the limits of theories of varieties of capitalism, providing assistance to expand its analytical scope.
\end{abstract}

Keywords: varieties of capitalism; Brazil; India; institutional complementarities; semi-periphery

\begin{abstract}
Resumo:
Nas teorias de Variedade de Capitalismo (VoC), adotadas nos países da OCDE, o Estado não cumpre um papel importante no sistema produtivo. Por outro lado, através da análise da trajetória dos países da semiperiferia , não há nenhuma maneira de descrever os mecanismos de complementaridade institucional sem incorporar o Estado no centro do modelo. Essas são as trajetórias do Brasil e da India. Para avaliar o papel do Estado como um ator estratégico na complementaridade institucional semiperiférica esta proposta sugere analisar o papel do Estado nos altos comandos da liberalização econômica. Em particular, o papel dos bancos públicos e fundos de pensão como atores anticíclicos e coordenadores da nova reestruturação societária e inserção externa adotada por grandes conglomerados no Brasil e na Índia nos últimos dez anos. Compreender isto é crucial para apontar os limites das teorias de variedades de capitalismo, prestando assistência para expandir o seu escopo analítico.
\end{abstract}

Palavras-chave: variedades de capitalismo; Brasil; India; complementariedades institucionais, semiperiferia

\footnotetext{
* (PhD in Political Science at IESP/UERJ, Associate Researcher at the Brazilian National Institute of Science and Technology (INCT), and Research Fellow at Humboldt Stifitung and Postdoctoral Researcher on Technische Universität Darmstadt,
} 


\section{Introduction}

$\mathrm{O}$ ne of the crucial questions in the trajectory of market-oriented reforms in the global semi-periphery is to understand the State's regulatory capacity, especially in the employment of the financial instruments at its disposal, contributed towards the emergence of a new structure of corporate property and a new productive regime. The trajectory of embedded neoliberalism observe in the semi-periphery has the potential to reinforce the dichotomies of national productive regimes, to the extent that internationalized tend to orient their investment, innovation, supply chain articulation and restructuring decisions (in other words, decisions that imply gains and losses in terms of income and employment) according to market strategies that are not complementary to the domestic economy (Kurtz and Brooks 2008). To what extent did the financial instruments controlled by the State contribute to increase of reduce this dichotomy, reflected in the pattern of integration if internationalized countries with the domestic economy, as well as in the duality in terms of access to rights and income between the formal or precarious social strata?

What is relevant for the general argument of this article is to emphasize that the accommodation of coalitions in the context of market-oriented reform in Brazil and India has found in the State the fundamental coordinator, largely supported by its own financial institutions in charge of allocating investment and credit. These institutional investors guarantee capital for the corporative adaptation in international settings at the same time they legitimize and accommodate conflicts of interest within the social coalition. The institutional investors act as a bloc of shareholders and seek to discipline and regulate the mechanisms of this new financial capitalism.

Through this analytical perspective, I consider that it would be possible to evaluate the role of the State as a strategic actor in institutional complementarity in countries of the semi-periphery. Particularly, through the role of public banks and pension funds as counter-cyclical actors and the coordination of a new restructuring of corporative property and the international inclusion pursued by Brazil and India in the last ten years. The understanding of this aspect is crucial to point out the limits of the theory of varieties of capitalism, offering support to expand its scope of analysis.

\section{Models of governance}

A significant portion of the literature on corporative governance focuses on the shareholding, which impacted on the transformation of corporate culture revolution, the developed under the leadership of Wall Street (Ho 2009). The center of this transformation was, evidently, the United States, where until the 1970s the corporation was deemed a stable social institution, responsible for the negotiation of multiple constituencies, evaluated within a long term interval that went beyond trimestral bottom lines. After the emergence of investment banking, in the wake of the 1980 
recession, Wall Street stipulated a new pattern in the cycle of corporate compensation, led by a set of financial institutions and networked agents (investment bankers, mutual and pension funds, stock exchanges, hedge funds and private equity companies) which incorporated a particular ethos, constituted by practices that became the cutting edge of globalized capitalism in the United States. These actors linked in networks, also became the carriers of financial theories and models that not only analyzed and described financial markets but also 'performatised' them (Callon 1998; Mackenzie 2006). This trajectory consolidated one of the pillars of the neoliberal model market economy, crucially focused on a pattern of scattered shareholders, in which proprietors and administrators are separated. This trajectory became consolidated particularly in the United States and became the cornerstone of orthodox economic discourse, although this cannot be generalized to include all capitalist economies.

One feature of the varieties of capitalism literature concerns the effects of the financing patterns on productive regimes. In the coordinated market economy model, the role of banks as mediators is predominant and complements the other variables, characterizing what has been dubbed "patient capital." In this variety, the returns on investments take place in the long run and the ownership network established by banks ensures of the fluctuations in employment, income technological levels and so on (Hall and Sosckise 2001; Albert 1993). Unlike what one could imagine in a context in which the corporate Anglo Saxon model hegemonic model prevails, the diffuse shareholder ownership model is not so common around the world. The fundamental question is that corporate governance systems vary not only among countries but also in the course of time in each country (Rajan and Zingales 2003). In most cases, whether in developed or developing countries, activism on the part of large stakeholders still plays an important role in corporate governance (La Porta et al 1999).

The system of corporate governance reflects public policy choices. Countries approve laws that configure incentives that, in turn, constitute systems of governance. Countries with strict anti-insider information trade rules and strong protection for minority shareholders and effective anti-trust regulations tend to follow diffuser ownership patterns and oversight through councils elected by shareholders. On the other hand, countries that adopt a bloc ownership model allow pyramid-shaped leverage systems and cross ownership, limiting competition and undermining protection for minority shareholders. In this context, interest groups fight for laws and regulations and can gear their preferences according go their position in the governance system (Aguilera and Jackson 2003).

Considering that politics is the independent variable to understand models of corporative governance and the possibilities of change over time, it is necessary to identify actors and how their preferences are organized within political institutions. According to the model proposed by Gourevicht and Shinn (2005), shareholders, administrators and workers develop distinct preferences regarding the regime of corporate governance. Furthermore, as there are more than one functions of 
preference for each group, different coalitions can be created. Owners administrators can be come allies to contain worker demands for salary and safety; workers and administrators can come together to ensure jobs and stable salaries in the company or, workers and owners can align to limit the costs of the agency of administrators and thus preserve the liquidity of investment and pensions.

One aspect of special interest here - to be further explored ahead - are workers who command their own pension funds and those who depend solely of the general public pension system. These two segments tend to develop distinct preferences in terms of their interests concerning corporate governance, as pension funds also become relevant institutional investors and the owners of shares in large corporations. This group doubles as workers concerned with income stability and employment and as investors with an eye on their investment savings. Depending of the profile of the investor, pensions funds - minority shareholders or large players - these actors tend to opt for a internal or external oversight mechanisms.

In order to understand corporate governance it is also necessary to assess how the relationship between stakeholders occurs in the decision-making process and in the control of corporate resources. Distinct forms of capital (banks, pension funds, individuals, families and so forth) posses different kinds of identities, strategies and timeframes. Considering the analysis conducted by Aguilera and Jackson (2003), in order to understand the national diversity of corporate governance it is necessary to understand the gaps in behavior and the institutional regulations that affect capital, labor and management.

One of the most promising theoretical strands useful in explaining the support of this kind of policy is coalition transparency (Gourevitch and Shinn 2005). Shareholding of labour unions from state-owned companies through pension funds has expanded exponentially in the last few decades, transforming them into actors with vested interests in corporate governance. Thus, workers organized in pension funds have acquired vested interests to the extent the pension remuneration depends on the variable income extracted from participation as minority stakeholders in strategic industry sectors of the economy. This union base has linked patterns of corporate governance to job security, to the extent that such practices can increase transparency, promote accountability and reduce trust hazards.

Research on this type of new activism has revealed unforeseen aspects. Part of the literature on corporate governance has associated the emergence of new institutional actors to the increase of agency costs and the undermining of minority stakeholders rights (Roe 2003). In general terms, the actions of pensions funds was linked to the resistance against reforms in the financial systems oriented towards stakeholder scattering. More recent comparative studies have shown, first, that movements towards stakeholder dispersion has resulted in the expansion and deepening of regulation, and that political actors and left-wing parties have acted decisively in the political construction of this process (Cioffi and Höpner 2006). ${ }^{1}$ 
In the semi-periphery, as we shall see, it has been hardly different. Pension funds and public banks stand out as the main champions of corporate governance. However, corporate governance does not mean per se the defense of self-regulation of the market, nor an orientation towards stakeholder dispersion, centered on the separation between stakeholder/owners and managers. In this scenario, the approach that treats institutional investors as the harbingers of morality in financial capitalism is pertinent, however this does not imply a sort political surrender to the logic of the self-regulated market, as the literature centered around research conducted in Brazil and the United States suggests (Ho 2009; Jardim 2009). As we shall see, this is because activism of these institutional actors in the semi-periphery is not limited to minority stakeholder position without the coordination with other political actors, such as the State. Furthermore, the degree of concentration of assets in the hands of these stock and credit market actors in the semi-periphery place them in a very distinct position relative to their North American and European counterparts, who fundamentally act as minority stakeholders with representation of the bloc that controls administration councils.

\section{The State and corporate governance}

The leads provided by the literature on corporate govemance are rather elucidating since, by establishing coalition patters as a variable to understand models of governance, it offers and excellent tool to understand the trajectory of internationalization semi-peripheral economies, taking into consideration the changes in the incentives and resources of strategic actors. However, considering the emphasis on the global semi-periphery, it is necessary to bring back the state to the center of any model of corporate governance and propose some coalition models in which the state is an active part of the equilibrium among strategic actors.

Part of the literature seeks to explain the growing significance of pension funds in relation to the limited fiscal powers of the State, the change in the equilibrium of power among bank and non-financial institutions and the financial services industry. The pension funds emerge in a context of withdrawal of the middle class from a distributive project of developed based on crossed subsidies or the transference income for other groups of consumers' public services. The intermediate income segments of society began seeing themselves as consumers of public goods and expect a level of quality similar to the market. In this sense, the functional coherence of the Welfare State, or that comes close to that, is being jeopardized by the fragmentation of the electorate in rival groups of consumers of public goods, all vying to maximize their lot of resources (Clark 2000; Streeck 2012). In this scenario, pension funds or organizations that represent them tend to become activists for the rights of minority stakeholders. As mentioned above, the variable of distinction in this scenario in relation to the Indian and Brazilian context is that in these countries in the semi-periphery pension funds do 
not exclusively play the role of minority stakeholders. They represent the fundamental supporters of public debt - they are the buyers of most public bonds issued. On the other hand, a significant part of the strategic economic sectors, they are not only the stakeholders, since they are in the control bloc next to public banks under the State's coordination. We shall see how this has become a crucial question among Brazilian and Indian institutional investors.

\section{Public banks and pension funds in corporate governance}

One of the central aspects of the market-oriented reforms both in India and Brazil is the divestment made by the State by means of privatization of its assets yet without necessarily losing its regulatory capacity. The State's withdrawal from the control of strategic companies did not necessarily represent the loss of voice and influence in strategic decision in crucial economic sectors. In fact, there are several studies that point out not only the maintenance of the capacity of coordination of the State's corporate decisions, as well as the expansion of regulatory power (Naib 2009; Nayar 2009; Schneider 2009b; Lazzarini 2011). This analytical prism has reinforced the Polanyian perspective of the dilemmas of collective action in deregulated markets and the need of the State to coordinate them.

The State's withdrawal from the control of strategic companies did not necessarily represent the loss of voice and influence in strategic decision in crucial economic sectors can only be understood to the extent we analyze the role of public banks and pension funds in the privatization process. This is not the place for a detailed foray into this process - to this end it suffices to say that privatization consortia had the prominent participation of these financial institutions, which inputted a significant amount of capital alongside private actors. It is necessary to emphasize the political context in which the bank as well as the pension funds were led to be a part of the privatization process. On one hand, the ideological siege of neoliberalism, whose rhetoric is centered around the fiscal crisis of the State manifest in the pension deficit. The complementary pension system as an active actor in the market serves as the antipode of its "poor cousin" the general public pension system. The capitalization model competed with the repartition model (Jardim 2009; Grün 2007).

The State as the agent of incremental market-oriented reform did not abandon its strategic position in the corporate governance of capitalism. It has, however, redefined the margins of maneuver in macro-economic so as to reconcile greater economic liberalizations and its consequences in terms of the autonomy of domestic policy, taking into account the political and social demands for a share of national income. This is the dilemma the literature has sought to qualify as neo-developmentalism.

What distinguishes this novel form of State activism regarding the previous trajectory is the emphasis on adjusting to the market rather than seeking domination. The previous brand of developmentalism was anchored in the shift from savings to 
investment, limitation of real income, and stratified and focused social policy. The novelty of the new model corresponds to an expansion public services without compromising public accounts generating a significant impact in terms of the reduction of inequality (Arbix and Martin 2010). The newfound protagonist role of the State represents an agenda adapted to the previous neoliberal consensus whose main aim achieve full employment in conditions of financial and price stability. To this end, the model shares some traits with previous developmentalism, as exemplified of the strengthening of the international political economy focused on the competition among nations carried out by domestic companies. However, the scenario in which the strategy unfolds is no longer that of protectionism. The legacy of reforms that led to economic liberalization and macroeconomic policy that created price stability were not only incorporated but also outlined a new model. Thus, the set of counter-cyclical social policies of the period did not truly infringe the tenets of orthodox fiscal and monetary policy (Ban 2013). What moderated these restrictions and created a margin of maneuver for a strategic intervention of the State was the possibility to employ public banks and pension funds. As an instrument insulated from the Executive branch, whose endowments are not subject to the Legislative's scrutiny, public banks were and still are the main comparative institutional advantage of the government in terms of development policy (Mettenheim 2010).

Unlike Brazil, however, the instruments of coordination of the Indian State do not seem to have been capable of fostering growth at the same time as employment and income expansion, as in Brazil during the last ten years. The expectation that manufacturing would lead the generation of productive jobs with trickle-down effects in the rest of the economy proved to be unrealistic. During this whole period marketoriented reforms in India, the growth of salary incomes was always below the level of productivity, combined with low employment elasticity in the most dynamic industrial sectors, and especially the services sector.

The ambivalence of a new form of State activism in a macroeconomic context full of restriction becomes clear in the way the so-called "commanding heights" of the state and the corporate world interact. The associations between institutional investors under the coordination of the State and private stakeholders established a degree of mutual interdependence and disciplining that confers visibility to a new and complex games of allegiances that needs to deal with a scenario of strong demand for distribution and a monetary and currency configuration that intensifies external competition and affects the variables of external competition and affects variables of employment and income.

By emphasizing the centrality of state activism this article contributes towards unveiling one of the aspects of political sociology of a literature that has been seeking to explore a new pattern of development consolidated in the last ten years in the global semi-periphery. By turning to a dimension of corporative governance and identifying its strategic actors this investigation seeks to evaluate how corporate coalitions, to a 
great extent brought together by State-led financial mechanisms outline the inclusive dimension of the model of growth. In a democratic context in which public policy linked to the budget possess a rather limited degree of liberty, the possession of financial instruments such as public banks and pension funds consolidate an arena of coordination between public and private interests of significant part of the economy. The business sector at large in all sectors of the economy need to negotiate corporate decision with large creditors and shareholders and, among them are included the pension funds representing workers and public banks representing the State.

\section{Interest groups and their preferences in Brazil}

Entrepreneurs who seek to internationalize do so to increases gains in terms of scale and, to this end, need capital to make share acquisition. However, these capitalists cannot expand their participation in the capital of other companies without diluting their own capital, and thereby risk an aggressive takeover. Thus, the presence of financing institution such as the National Bank of Social and Economic Development (BNDES) and the pension funds, endowed with shareholder participation with veto power over mergers and acquisitions, has served as a roadblock to the process of internationalization.

The State, through public banks, and the syndical base of internationalized sectors of the economy, through pension funds, have been active in the restructuring with the national entrepreneurial community. This process began during the marketoriented reforms and not necessarily new in Brazilian corporate history (Evans 1979), when private actors participated in the privatization consortia intertwined with state and pension fund actors. Up until then, public banks and pension funds would input capital with minority partners, had a golden share but did not have voice nor arbitrated in corporative decisions, as became very clear in the case of the rumors in the case of privatization of the telecommunications sector. The government preferred to auction the shares of the controlling bloc instead of making public offers of shares, because this would guarantee the best alternative for the capture of price control and, thus, a larger volume of resources to reduce the public debt. ${ }^{2}$ In order to guarantee greater efficiency in this strategy, the government approved article 254 of Law 6404/76 that guaranteed to minority stakeholders the right to sell their shares at the same price paid to the controlling group in the case of an asset transfer, an instrument know as the "tag along." This measure evidently undermined minority stakeholders and guaranteed the government the upper hand in all privatization sales. On the other end, the law allowed companies to issue shares without voting prerogatives (preferential votes) in an amount of up to two thirds of the total stock of capital. This allowed that the control of one country could be guaranteed with only $1 / 6$ of total capital (Gorga 2006). With the consolidation of the new rules of corporate governance in the financial market and the exponential growth of variable assets in the last ten years the BNDES pension 
and participation funds have become central actors in most all shareholder structure restructuring in Brazil. Despite the vertiginous of the financial capitals as a source of financing, especially through Initial Public Offerings, the fund for long term financing and high risk ventures still depends on public financing agents.

According to the Center of Capital Market Studies (Cemec), of the R\$ 1.2 trillion of corporate debt, only $24 \%$ (i.e 300 billion) are financed by the financial capital market. ${ }^{3}$ Banks, and particularly public banks, are those who guarantee the financing of the long term corporate investment in Brazil. Furthermore, considering that the BNDESPar and Previ are the main financial actors in the capitals market, at the helm of a portfolio worth, respectively, $\mathrm{R} \$ 100.6$ billion and $\mathrm{R} \$ 90$ billion, it is possible to say with such a significant presence of these actors in the capital market implies a coordinated mode of financing. There is abundant literature identifying the Brazilian economy as a hybrid model in which the State and private actors act in coordination by means of the financing of public banks (Stallings and Studart 2006). The role of the capital market still is limited not only in terms of the still small number of companies listed in the stock exchange, but also to forms of financing that do not fulfill long term needs, since it focuses mostly on working capital. The volume of BNDES disbursements is still higher than the volume of resources available via the stock market. In parallel to the large investment funds in the capital market there are the State-owned branches and pension funds, especially the BNDESPar and Previ. BNDESPar detains the country's largest portfolio, participating directly in 3030 companies and exercising a high level of oversight (Schapiro 2010).

The mechanism that in fact ensures the BNDES's capacity to oversee is based on the so-called 'acordo de acionistas', or shareholders' agreement, which governs the relationship between investors and beneficiary companies. Based on contract clauses, the bank formally guarantees participation in the administration of the company and backs corporate decisions. The shareholders' agreement comprises: 1) previous consent by the BNDES concerning certain decisions, as, for example, (a) shareholding decisions such as the increase or reduction of capital; (b) mergers and acquisitions; (c) investment in other areas other than those belonging to the core activities of the business; (d) the concession and acquisition of technology; 2) participation in the Council of Directors; and 3) free access to the company's information (Shapiro 2010). Unlike England and Eastern Europe whose model of privatization was based on the strategy of shareholding privatization, the Brazilian strategy was based on the selling of control of majority stakeholders. This model applied to $86 \%$ of the total of privatizations, being that $53 \%$ of the buyers participated as associates in mixed consortia, made up of private domestic groups, international groups and actors linked to the government, basically public banks and pension funds (De Paula; Ferraz and lootty, 2002). 


\section{Analysis of segments and actor behavior}

As mentioned above, the BNDESPar and the pension funds (especially Previ) are the main institutional investors in the Brazilian capital market. According to data provided by the National Superintendence of Complementary Pension (Previc), until 2011, the investment portfolio of the pension fund amounted to $\mathrm{R} \$ 539.7$ billion, formed by 360 entities and 2.6 million individual members, or $3 \%$ of the economically active population. The funds' portfolio is mostly comprised of public bonds (57\%) and stocks (32.4\%). Brazil ranked 8th in the world in pension funds, being that they represent $17 \%$ of the GDP. ${ }^{4}$ Although it lags behind leading capitalist countries in terms of pension funds, Brazilian pension funds have grown at an annual rate of $15 \%$ in the last 10 years, surpassing all large economies in terms of growth rate, according to Towers Watson consultants. As it is impossible to assess all complementary pension entities, the objective here is to restrict the analysis to the three largest ones: a Previ, which represents the employees of Banco do Brasil; Petros, the employees of Petrobras; and Funcef, which congregates state bank Caixa Econômica Federal's pensioners.

\section{Analysis of funds}

When he left the presidency of the Funcef, after eight years, Guilherme Lacerda had consolidated the third largest pension fund in Brazil, whose assets were estimated be worth $\mathrm{R} \$ 43.8$ billion. According to data provided by the Abrapp, was Funcef the second fastest growing pension fund in the last eight years $-327.8 \%$. Cumulative profit of fund assets was $300.3 \%$, easily surpassing the target of $46 \%$. Despite the structural reduction of interest rates between 2003 and 2010, Funcef did not significantly reduce the application of funds in fixed-return investments, but expanded applications in variable income fund - a portfolio worth approximately $\mathrm{R} \$ 100$ billion. This is the largest pension fund in Latin America and the 24th globally, according to a ranking devised by Pensions \& Investments magazine. ${ }^{5}$

Next to pension funds, the BNDES's holding branch, BNDESPar, has also been undergoing rapid transformation. Since 2007, the fund has increased grown five fold, increasing its assets from 25 billion Reais in 2007 to 125 billion Reais in 2011. The bank's "shopping spree" in the context of the financial crisis enabled an enormous capacity for debt so that Brazilian companies could turn to acquisitions within the country and abroad. This also expanded the direct shareholding participation of the fund in the creation of large conglomerates. The company's portfolio, considering share, debentures and funds are concentrated mainly in the oil and gas (36\%), mining $(21,2 \%)$, electrical energy $(11.7 \%)$, food $(9.8 \%)$, telecommunications $(4.4 \%)$ and paper and cellulose $(4.3 \%)$ sectors. $^{6}$

The State, through its public banks and pension funds, can act as an active member in control blocs, with shareholding powers that include vetoes. In the case of mining, 
energy generation and distribution, transportation, oil, telecommunications, and food these institutional investors act as blockholders, with, at least, veto powers.

\section{Exemplary cases: mining and energy}

The case of Vale, the minig company, is emblematic because the BNDESPar and pension funds currently hold a majority of the company's ordinary shares (with veto powers), the power to appoint the president of the administration council and joint decision over the company's president. When Vale was privatized in 1997 for US\$ 3.3 billion to a group led by Benjamim Steinbruch of CSN, the national steel company, BNDESPar and pension funds detained only 35\% of shares. In 2011, Vale announced a new profit of US\$ 6.6 billion and a market valuation of R\$ 250 billion, while BNDESPar and pension funds accounted for $60 \%$ of the company's shares. What led to this extraordinary change and what were the implications on the behavior of actors? The first factor that must be highlighted is that since privatization institutional investors never lost the veto power in strategic decisions, a condition acquired once a $25 \%$ share is achieved. Since privatization, state and private actors, both national and foreign, have been adjusting the shareholding structure of the company in the attempt to strike a balance to unite this tripartite consortium. Initially, the un-crossing of shares between the CSN and Vale in 2001 allowed Steinbruch to leave Vale and assume control of the CSN, while Bradesco and Previ expanded participation in Vale, assuming control. In 2003, Bradespar sold $18.2 \%$ of its part of the bloc to Mitsui, a Japanese company, prompting the other partners to thwart the emergence of new strategic actors. This move became clear with the acquisition of $11.6 \%$ of the shares of InvestVale by BNDESPar, blocking the possibility of giving a foreign partner veto power in strategic decisions. ${ }^{7}$

After 2006, Vale began a cycle of acquisitions internationally and became, next to Petrobras, one of the largest companies in Brazil. It is important to highlight that the growth of assets of the company through its acquisitions in Brazil and abroad occurred in parallel to the expansion of the share participation of institutional investors. At the same time, the institutional investors at Vale that were part of the control bloc defended a model of corporate governance beyond the reach of the Brazilian stock exchanges, the Novo Mercado and BM\&F. By planning the acquisition of mining company Xstrata in 2008, Vale planed to expand its capital in the London stock exchange, but its request was denied based on the grounds that the company would have to abandon its share structure model that distinguished between preferential and ordinary shares. Controlling shareholders do not admit the merging of shares as this would dilute control and create a company with diffused control. ${ }^{8}$

Also active in the energy section, the pension funds and BNDESPar play a crucial role. Previ has strategic shares in two holdings in the electrical sector: $32 \%$ of the capital of the CPFL and 39\% of Neoenergy. As in the steel and telecommunications sectors, 
cross-ownership was undone and this allowed funds, in coordination with public banks, to chose business groups who would be more willing to follow an investment agenda in line with the energy-supply priorities of Brazil in the long term.

On the other end, in energy generation and large infra-structure works, financial innovation led to the creation of large-scale Investment Funds with the prominent participation of the BNDES and pension funds. As a result of the demand by institutional investors such as the pension funds, in 2009 the National Monetary Council expanded the upper-limit of investment in variable income relative to the net assets of the pension funds, from $50 \%$ to $100 \%{ }^{9}$

This change had a direct impact on the creation of investment funds in energy generation (such as hydroelectric) and investment in equipment for the oil industry. In this regard, Invepar and FIP Sondas stand out. The first was created in 2000 and is an investment fund geared towards road infrastructure and transportation, in a partnership formed with Previ, Petros and Funcef. The second is an investment fund specialized in the construction of deep-sea leads for the exploration of oil in the presalt layer. The fund's model comprises institutional investors (Previ, Petros, Funcef and Valia) and financial actors (Bradesco and Santander) as stakeholders and intends to raise US\$ 4.5 billion, $80 \%$ of which should be financed by the BNDES with resources of the merchant marine and the remaining by the other partners. ${ }^{10}$ In combination with the revival of the naval industry, this financial model for the import substitution of lead is one of the main wagers in technological innovation to explore the pre-salt frontier.

Considering the fiscal and credit effort by the State to ward off the crisis in 2009 and 2010 and keel investment flowing, it is necessary to stress that directed credit accounted for $62 \%$ of the increase in the stock of credit, further propelled by the role of public banks (Barbosa 2010). The Treasury already lent the BNDES more than R\$300 billion since 2009, which allowed the bank to promote mergers and acquisitions in a context of low international liquidity and high leverage as a result of the subprime market. The 2008 financial crisis added an external component in this new effort of coordination between pension funds and public banks. Many Brazilian companies were highly exposed in currency derivatives at the time of the crisis and became insolvent. The BNDES and the pension funds openly acted to promote mergers with companies in the same sector so as to achieve global gains in scale. This was the case of Sadia and Perdigão, which resulted in the creation of BrasilFoods (with 27.2\% shares in the hands of pension funds); and of Acacruz and Votorantim, creating (30.4\% shares with veto rights owned by BNDESPar in partnership with Votorantim). These two companies became the two largest conglomerates in their respective fields.

Considering the new literature on industrial policy (Rodrik 2004), this strategy has a few contradictory aspects. On one hand, it develops sophisticated mechanisms of risk management and funding and absorbs the externalities of coordination, while in the other hand it is uncertain whether that this strategy in sectors that are already competitive internationally will entail the development of research in technological 
frontiers, as the Brazilian industrial policy hopes. This has been the main critique of those who evaluate the trajectory of the Brazil in international trade, that is, the support to merger and acquisitions provided by the BNDES has favored industrial sectors with low technological aggregation (Almeida 2009).

\section{Corporative governance in India}

According to data contained in the IMF's economic overview, in relation to the ten largest economies of the world, India was ranked fourth, with a GDP growth rate of $6.5 \%$ and per capita growth of $4.7 \%$ between 1990 and $2010.52 \%$ of the GDP in India was generated by the services sector, while agriculture and industry accounted for $22 \%$ and $26 \%$, respectively. In terms of employment, rural workers accounted for $2 / 3$ of the total workforce, being that more than $90 \%$ of the total workforce is employed in disorganized sectors of the economy. ${ }^{11}$

Every time this data appears side-to-side it tends to cause perplexity, specially when trying to understand the mechanisms of credit and financing that structure the country's productive regime. An important strand of the literature on patterns of financial intermediation has brought attention to the fact that the financing preferences vary according to the size of the company. The degree of formalization for the access to credit through the capital market and bank in a scenario of acute formal (legal) disorganization of contract relationships inhibits access in larger scales. For small and medium-sized companies the importance of alternative financing, supported by non-legal mechanisms such as reputation trust and reciprocity, and which are not originated from bank loans or fund-raising in the capital markets has been crucial to ensure growth. Even among the large companies the crucial channel of financing are internal sources, followed by alternative sources.

This does not imply that bank financing or market capital funds will not produce results in terms of investment and growth capacity. However there is a set of rifts related to the size of the company and participation (or non-participation) in the capital market. As in Brazil, in India the capital market is not the mains source of credit for investment in large companies. On the contrary, corporations in strategic sectors refuse to open capital or negotiate shares with direct control. Usually, the state keep veto power over the companies of the sector. As the informal sector in India is larger than Brazil, the role of informal mechanisms of financing is evidently bigger in the Indian case, but the strategic industrial of these countries are intertwined with the sources of credit provided by state banking. If the weight of these non-formal mechanisms of access to credit is, on one hand, associated to the huge informality of the labor market, and, on the other, it tends to be a counter-weight guaranteeing the Indian State's capacity of financial coordination. This gap regarding the size of the company and access to financing constitutes one of the determinants of the trajectory of integration of the Indian economy in the context of globalization. 
Table 1 - Non-financial Indian companies and Sources of Financing

\begin{tabular}{l|c|c|c|c|c|c|c}
\hline \multicolumn{5}{c}{ Non-financial Indian companies and Sources of Financing } \\
\hline & \multicolumn{3}{l|}{ All companies } & \multicolumn{2}{l}{ Large Companies } & \multicolumn{2}{l}{$\begin{array}{l}\text { Small and medium- } \\
\text { sized companies }\end{array}$} \\
\hline & $\begin{array}{l}\text { All } \\
\text { companies }\end{array}$ & $\begin{array}{l}\text { Large } \\
\text { Companies }\end{array}$ & $\begin{array}{l}\text { Small and } \\
\text { medium- } \\
\text { sized } \\
\text { companies }\end{array}$ & $\begin{array}{l}\text { Listed } \\
\text { in stock } \\
\text { exchange }\end{array}$ & $\begin{array}{l}\text { Non- } \\
\text { listed }\end{array}$ & $\begin{array}{l}\text { Listed } \\
\text { in stock } \\
\text { exchange }\end{array}$ & $\begin{array}{l}\text { Non- } \\
\text { listed }\end{array}$ \\
\hline $\begin{array}{l}\text { Internal } \\
\text { Sources }\end{array}$ & 45.29 & 46.6 & 15.11 & 58.32 & 34.51 & 39.49 & 11.16 \\
\hline Market & 6.47 & 5.47 & 9.98 & 8.09 & $2, .6$ & 24.87 & 7.57 \\
\hline Banks & 18.18 & 18.86 & 25.02 & 12.18 & 25.75 & 19.42 & 25.92 \\
\hline $\begin{array}{l}\text { Alternative } \\
\text { finances }\end{array}$ & 30.6 & 29.08 & 49.89 & 21.42 & 36.98 & 16.21 & 55.34 \\
\hline $\begin{array}{l}\text { Number of } \\
\text { cases }\end{array}$ & 12,344 & 4,760 & 9,014 & 1,001 & 3,759 & 400 & 8,614 \\
\hline
\end{tabular}

This table offers evidence regarding the origin of funds for non-financial institutions (2001-2005), according to the database elaborated by Prowess / CMIE. 1) Internal sources are defined as net income after dividend distribution + depreciation + provisions; 2) financing via market includes shares + bonds issued in capital market; 3) bank financing includes debt or loans from banks; 4) alternative financing includes all private sources outside the market, whether it by from banks or the capital market. (based on Allen et al, 2012)

The trajectory of privatization in India, called divestment, consisted of a reduction of government equity participation in companies, yet without loss of veto power and voice in most economic sectors. Observing the composition of India's largest companies, it is clear that the State is still by far the dominant actor in the economy, particularly in infrastructure, finance and oil. Among the 500 most valuable companies in India, which together account for $90 \%$ of the capitalization of the Bombay stock exchange, $60 \%$ are part of conglomerates - or business houses as they are called in India. This is family business groups still play a crucial role in the Indian corporate sector. The ownership structure of these companies is analogous to the pattern of Brazilian business groups, characterized by the widespread pyramid-shaped scheme, cross-ownership and the use of private companies and non-public trusts as owners in companies. In addition to the presence of families as large individual shareholders, institutional investors - here understood as government-sponsored mutual funds and insurance companies, banks and development financial institutions that are also creditors of long-term institutional investors and foreign companies - held more than $22 \%$ of average shares of large companies in India (Chakrabarti, Megginson, and Yadav 2008).

The consolidated literature on corporate governance in India identifies the business houses as a crucial instrument. This model emerged from the role of the management agent, who was basically the promoter of new ventures that entered with a minimum amount of equity capital, raising the rest of funds through public offerings or from public financial institutions. This dynamic allowed the emergence of conglomerates, concentrating control and decision-making at the apex of its structure, coordinating crucial decisions such as direction of investment, allocation of 
profits and the relationship between the various group companies. The control does not require a majority or even a substantial minority of shares. It can unfold as crossparticipation in administrative and intercorporate investment advice. At the same time, the emergence of these conglomerates converted public financial institutions into key actors, since they held the majority shareholding in major Indian companies. The use of development banks by the government to promote industrialization assured extensive interest in the property and instrument of voice and veto within companies. The instrument for this has been the appointment of internal cadres for the board of directors of companies (Reed 2002).

State-owned enterprises, which are the major corporate conglomerates, are not present in the stock exchange and therefore their source of funding is predominantly the capital market. According to the literature, the corporate system in India can be described as a hybrid between a outsider with dispersed share ownership profile alongside a corporate system based on banks with strong presence of large concentration of power in equity ownership of banks, households and other actors (Som 2006).

Much of this configuration was originally determined by the regulatory regime after independence. One of the primary mechanisms by establishing barriers to private investment was the IDRA (Industries Development Regulation Act). Established in 1951, the law required that all existing industrial units obtain licenses from the central government, thus encouraging entry barriers. On the other hand, the industrial policy resolution (IPR) established in 1948 has listed various segments of industries whose development would occur at the sole expense of the State. This resolution allowed the government to create a service sector and public service industries. In 1969, in the political context of a new wave of nationalization, the government instituted a law that combined industrial licensing with an asset-based classification of monopoly. The MRTP (Monopolies and Restrictives Trade Practices Act), required private sector business, whose assets surpassed a certain upper-limit, to acquire additional licenses to increase investments.

The wave of nationalizations ultimately conditioned measures of market reserve and protection to small and medium enterprises to distributive instruments such as guaranteed employment. These policies fostered the formation of industrial capacities, particularly in engineering, pharmaceuticals, chemicals, fertilizers and petrochemicals. In parallel, the government intervened heavily in the financial market during the 1970s and 1980s by means of three instruments: 1) allocation of credit through loans to priority sectors and credit approval; 2) controls on deposit and lending rates; and construction of an infrastructure bank the licensing of banking branches, which ensured significant expansion of a baking-based society. This agenda has been achieved through the regulatory role of Reseve Bank of India, enacted in 1974 , encouraging the public to increase their lending to the priority sector by up to $1 / 3$ or more by the end of the decade banks. After 1980, the RBI raised once again the 
lower-limit for the proportion of credit to priority sectors to more than o $40 \%$ of net bank credit to the end of year 1985. Within this overall limit, the RBI stipulated that agriculture would receive $16 \%$ of net bank credit and, of that amount, the landless and small farmers should receive 50\% (Panagariya 2008).

Furthermore, $90 \%$ of the assets of pension funds and $50 \%$ of the assets of life insurance were forced to acquire government bonds. State-owned banks control about $85 \%$ of the sector in terms of share in deposits. The Indian banks lend about $60 \%$ of their deposits, distributed in the proportion of 39\% to public sector enterprises, $30 \%$ for discretionary corporate loans, $11 \%$ for agriculture and $7 \%$ for domestic companies and $13 \%$ for small private companies. Since the last three segments - which together account for $31 \%$ of bank credit - are classified as "priority sectors" in India (Bardhan 2010). One of the objectives of bank nationalization of 1969 and the ensuing wave of regulations was to expand access to credit for areas of economy with limited access to credit and whose loans guaranteed no return. There is considerable debate concerning the effectiveness of the role of state banks in providing credit to undercapitalized segments of the Indian economy (Banerjee, Cole and Duflo 2004). There is no doubt, however, that compared to private banks, public banks pledged substantially more credit to agriculture, rural areas and the government.

\section{Financial Institutions in India}

While $90 \%$ of the assets of pension funds in India are intended for the financing of public debt of the country, this proportion is slightly lower in Brazil - approximately $65 \%$. The differences between the two countries do not stop there. The degree of coverage of pension systems in India is much lower compared to Brazil. Only $20 \%$ of the workforce relies on some form of security. Apart from this limitation of coverage, there is also a divide regarding standard actuarial pay for pension plans that guarantee the public sector a major advantage compared to other workers segments. There are at least seven forms of pension plans: the Employees' Provident Fund Organization (EPFO) - targeted at employees in the private sector; funds of state enterprises; the civil servants; occupational pension schemes (Occupational Pension Schemes or Superannuation Schemes); voluntary savings plans with tax advantages; plans for unorganized sectors (Asher and Nandy 2006). The regulatory framework for pension funds has changed since 2004 when the government launched the New Pension Plan (acronym NPS) for all public servants from that year. Up to that point civil servants had received pension from a non-contributory scheme, with earnings pegged to prices and wages. The diagnosis that sustained the introduction of this new plan was the expectation of fiscal unsustainability, supported by evaluations made by the World Bank (World Bank 2005). The fact is that the NPS allowed that $50 \%$ of assets in this scheme of pension funds be invested in stock/equity market, under supervision of the PFRDA. ${ }^{12}$ The stated purpose here was to move away from pension plans with defined 
benefit to an arrangement based on defined contribution i.e, a shift from an allocation model to one of capitalization - a process already well underway in Brazil (Grün 2005). To this end, the literature favorable to this model focuses on the use of fund assets as a means of fostering liquidity in the stock market, rendering it an instrument of longterm financing through private equity. On the other hand, this same literature argues that the funds are not used as instruments to finance the deficit through the purchase of securities (Ashraf 2011). The immediate consequences, as also observed in Brazil, is the strengthening of the standard tier-based system of access to rights.

Until 1990 the largest blocs of shareholders of all major Indian companies consisted of financial institutions, a position consolidated by the commitment to convertibility in loan agreements (loans into shares through direct underwriting of public issues by the loaning company). These institutions were fundamentally formed by development banks with different vocations, as, for example, the Industrial Development Bank of India (IDBI), the Industrial Finance Corporation of India (IFCI), the Industrial Credit and Investment Corporation of India (ICICl), the Industrial Reconstruction Bank of India (IRBI). A similar process can be observed in the convertibility agreements offered by the BNDES. Until 1991, financial institutions were not committed to overseeing the companies in which they were shareholders. Up to then, the objective of financial policy in India was to extend loans for industrial development without considering the recovery of assets. As a result of ongoing operational reforms since 1991, financial institutions have been forced to take responsibility for their lending and investment choices. As lenders have become guarantors risk of their investments, there are indications that banks began to act more actively in corporate governance in the companies in which they have a participation in the ownership structure (Sarkar and Sarkar 1998).

While the small investor has a predominant share in the capital market, relying on the foreign market; large firms do not draw their source of funding from the stock market, nor are they willing to follow their rules of corporate governance. When it comes to strategic sectors of the economy a system of internal coordinate funding, supported by banks prevails. An example of the monitoring role of public banks can be seen in the IDBI, which until 2000 had 470 counselors scattered around 1,026 companies, most of whom were employees of the institution; the Life Insurance Corporation (LIC - the largest life insurance fund in India) had 124 appointed directors sitting on the boards of 171 companies, being half of them retired former employees of the company; $\mathrm{ICICl}$ has 231 listed companies overseeing 436 (Banaji 2001). At the same time, enterpriselevel studies confirm the importance of debt in capital structure: roughly $4 / 5$ of the total external funds to loans and provisions and current commitments originate from banks and development financial institutions (Sarkar and Sarkar 2008).

Comprehension of the behavior of institutional investors in the coordination of investments in India will enable us to understand the coordination capacity of the State regarding corporate investments. Data produced by Khan (2006) shows that 
the main shareholders of Indian companies are: 1) directors and their relatives; 2) corporate groups; 3) foreign investors; 4) the loan institutions, composed of three financial institutions and state development corporations funded by the State; 5) institutional investors, mutual funds state (Unit Trust of India) and three state insurance companies of state insurance; and 6) public. Of the six groups, the first five can be considered major shareholders or shareholders' bloc. The high proportion of concentrated share ownership by directors and relatives corresponds to the predominance of family-owned businesses, a typical feature of corporations in India and Brazil. Among other blocks of shareholders are institutional investors groups of companies, monopolized by the Unit Trust of India. Financial institutions, on average, hold less shares compared to institutional investors. The different types of financial institutions separately hold blocks of shares much smaller compared to other countries. However, given that approximately $90 \%$ of these financial institutions are controlled by the government, together they form a much larger compared to more homogenous blocks in other countries. The participation of institutional investors mutual investment funds and insurance companies, almost all of which owned by the government - is also significant.

The literature has consolidated the assessment that the context of an excessively closed economy, abundant supply of credit and lack of selectivity in relation to projects chosen to receive subsidies would result in crony capitalism. On one hand, over-indebtedness; on the other, the role of Development Finance Institutions as shareholders. Until the early 1980s, it was possible to start an industrial project by borrowing from state banks and secure control with only $15 \%$ of capital. Until 1991 , out of the 528 companies listed on the stock market with sales exceeding $\mathrm{R} \$$ 500 million, $65 \%$ of total capital was borrowed. What is more, $20 \%$ of these funds originated from the three largest state banks. Even ten years after the beginning of economic liberalization, a substantial fraction of the shares of companies in the Indian private sector belong to development financial institutions, nationalized insurance companies and mutual funds owned by the government, such as the Unit Trust of India. What critics point out is that this type of indirect state ownership did not result in healthy governance by stakeholding state financial institutions, despite the fact that the three major development financing institutions - IFCI, IDBI and ICICI - were well positioned to play a similar role to the German hausbanks, whether as major lenders or as large shareholders (Goswami 2001).

The capacity of the Indian State to remain in the commanding heights of the economy even after the period of market-oriented reforms calls for a critical reading of this new role. On the one hand, the bank nationalization of 1969 expanded the number of branches across the countryside, allowing the expansion of the bank system, higher domestic savings and, ultimately, capillary access to credit; on the other hand, the persistent degree of informality in the labor market, which borders $90 \%$, India is situated at a level of informality of financial intermediation whose pattern is 
not coordinated by the banks. What is perhaps more productive in analytical terms of analysis is to understand how operational reforms of public banks in the context of liberalization of the 1990s contributed to increase even more the opportunities for banking inclusion as had been done until the beginning of the reforms (Santana 2012). In other words, how is it possible to comprehend the standards of financial intermediation as an element of corporate governance that determines sectors of the economy that will successfully integrate into dynamics of globalization, while the rest of the economy does not articulate with the dynamic and internatinalized segments and act as a reserve labor with low productivity? Although the theory of economic enclaves is usually associated with theories of imperialism, the insertion of India in the global economy follows a pattern of economic dualism that is very similar to the models criticized by dependency theories.

India is perhaps the exemplary case of economic dualism, which means a large gap in productivity between workers in the organized and unorganized segment of the economy. What the literature has highlighted is such dualism is based on distinct patterns of access to capital for investment, with large companies absorbing resources provided by banks at subsidized interest rates, while the rest of the economy relies on informal sources with higher interest rates. The dualism ultimately reinforces the reproduction of labor without industrial skills, complemented by a state-led educational policy that favors targeted qualification for intensive segments in capital and technology, while basic education is unsatisfactory. The legislation for the protection and encouragement of small-scale industry enhances the replication of small units that have no incentive to expand in scale and productivity (Mazumdar and Sarkar 2008; D'Costa 2003). In addition, the finance establishment has restricted the possibility of growth-oriented strategies to maintain equivalence wages with productivity growth. According to the literature, it has been possible to verify since the beginning of the reform agenda greater domestic and external deregulation of financial flows, a deflationary bias (transmitted to domestic macroeconomic policies), and a diminished possibility of targeting the credit to strategic sectors and laborintensive (Ghosh 2011).

\section{Conclusion}

Part of the literature on corporate governance in Latin America attributes ownership concentration to the standard hierarchical model of control. This pattern is supposedly due to the lack of effective separation between management and control, the predominant role of family ownership and the existence of multi-sectoral clusters (Schneider 2008). The mechanisms of institutional complementarity in a hierarchical market economy do not yield enough increasing returns that could result in the displacement of the technological scheme of production. Thus, multi-sector business groups restructure themselves to overcome the high degree of macroeconomic 
volatility in the market and to defend themselves from the competition, regardless of complementary technology among sectors or of them being part of the same supply chain. With multinational corporations dominating high-tech manufacturing, domestic business groups are concentrated in low-technology sectors such as commodities and services with a lower incentive to invest in Research and Development. Multinational corporations in turn choose to invest in markets with products and established technologies and foreseeable market demand. Lastly, the state is seen as the institution that historically reinforced the core characteristics of hierarchical market economy since it regulated the market for capital, labor and technology (Schneider 2009a).

Schneider's analysis employs a kind of generalization quite similar to that made by Lazzarini (2011). They see the strategic actors in corporate governance as arbitrary violators of a market order. The very idea of hierarchy proposed by Schneider in the corporate decision-making structure is a vision that blends the theories of patrimonialism mobilized by Lazzarini to understand the prevalence of the statecommanding heights state as the central core of equity ownership networks. Despite this bias, the authors manage to gather data that demonstrate that the State as an institutional investor through public and state-owned banks produced a new form of equity overlapping and secured momentum so large business conglomerates could withstand the onslaught of foreign competition, while guaranteeing at the same time funding for global expansion.

With this in mind, this present article seeks to demonstrate that there is no state (or para-state) financial patrimonial elite, to which supply chains are subordinated. Therefore, nothing indicates this is a variety of capitalism of hierarchical nature. Strategic economic actors, both public and private, establish corporate alliances and coalitions of mutual interest that have enabled the competitive internationalization of relevant industries. Technological aggregation and financial capacity of relevant sectors such as civil aviation and agri-business in Brazil, the pharmaceutical and software industries in India could not be comprehended unless as a function of the strategic alliances of public financial institutions and state-supported research. This article performed a financial analysis of these coalitions in order to understand a variety of state-coordinated state capitalism, describing aspects of their institutional complementarities.

\footnotetext{
Notes

' See interview with the president of Previ, the Bank of Brazil workers' pension fund: Consuelo Dieguez, "Sérgio Rosa e o Mundo dos Fundos", Piauí, edição 35, agosto de 2009.

${ }^{2}$ Only 5\% of total sales of the national de-nationalization, carried out between 1991 and 1998, were made through public offers, while $91 \%$ were made through auctions and $4 \%$ offered to employees of privatized companies.

${ }^{3}$ Carolina Madil, Anbima quer forçar venda pulverizada de debêntures, Valor Econômico, 04/04/2011 ${ }^{4}$ Azelma Rodrigues and Luciana Otoni (2011)"Novo xerife dos fundos de pensão aposta em expansão do setor, Valor Econômico, 02/05/2011".

${ }^{5}$ http://www.pionline.com/article/201 10905/CHART01/110829945 (acesso em 29/02/2011).
} 


\begin{abstract}
${ }^{6}$ Leila Coimbra, Compra de ações pelo BNDESPar já atinge R\$ 42 bilhões, Folha de S. Paulo, 01/07/2011. ${ }^{7}$ Ivo Ribeiro e Silvia Fregoni, Com fundos e BNDESPar, governo retomou controle, Valor Econômico, 04/04/2011

${ }^{8}$ Vera Durão e Janes Rocha, Novo Mercado? Não, obrigado, Valor Econômico, 15/11/2009.

${ }^{9}$ Julianna Sofia, Fundos de pensão poderão correr mais riscos, Folha de S. Paulo, 25/09/2009.

${ }^{10}$ Vera Durão, Previ entrará na Sete Sondas, criada pela Petrobrás, Valor Econômico, 24/02/2011.

${ }^{11}$ IMF World Economic Outlook Database, April 2011 (accessed on http://www.imf.org/external/pubs/ft/ weo/2011/01/weodata/index.aspx); The disorganized sector of the economy includes, according to the official definition (1) all enterprises, except for units listed in Section $2 \mathrm{~m}$ (i) and $2 \mathrm{~m}$ (ii) of the Factory Act of 1948, and Bidi and cigar workers (work conditions) Act of 1966, e (2) all enterprises, except those managed by the central government (central, state and municipal agencies.

12 Pension Fund Regulatory and Development Authority.
\end{abstract}

\title{
Bibliographical References
}

AGUILERA, RUTH and GREGORY JACKSON. (2003) The Cross-National Diversity of Corporate Governance: Dimensions and Determinants. Academy of Management Review, 28(3): 447-465

ALMEIDA, MANSUETO (2009) Desafios da Real Política Industrial Brasileira do Sec. XXI, Brasília: Texto para Discussão n. 1452, IPEA

ALLEN, FRANKLIN ET AL (2012) Financing firms in India, Journal Finan. Intermediation, 21; 409-445

ARBIX, GLAUCO e SCOTT MARTIN (2010) "Beyond Developmentalism and Market Fundamentalism in Brazil: Inclusionary State Activism without Statism", Workshop on States, Development, and Global Governance, Global Legal Studies Center and the WAGE, University of Wisconsin-Madison,

ASHER, MUKUL and AMARENDU NANDY (2006) Reforming provident and pension fund regulation in India, Journal of Financial Regulation and Compliance, Vol. 14 Iss: 3 pp. 273 - 284

ASHRAF, IMAM (2011) Pension Fund Management in India: government role and regulatory issues, Zenith - International Journal of Multidisciplinary Research, Vol.1, Issue 7, November

BAN, CORNEL (2013), Brazil's Liberal Neo-Developmentalism: New Paradigm or Edited Orthodoxy? Review of International Political Economy, Volume 20, Issue 2

BANAJI, JAIRUS (2001) "Corporate Governane and the Indian Private Sector", Queen Elizabeth House Working Paper Series, Oxford University, May

BANERJEE, ABHIJIT; SHAWN COLE; and ESTHER DUFLO (2004) Banking Reform in India, India Policy Forum, 1:277-323

BARBOSA, NELSON (2010) Latin America: Counter-Cyclical Policy in Brazil: 2008-09, Journal of Globalization and Development, Volume 1, Issue 1

BARDHAN, PRANAB (2010) Awakening Giants, Feet of Clay: Assessing the Economic Rise of China and India, Princeton University Press

CALLON, MICHEL (2007) What does it mean to say that economics is performative? Do Economists Make Markets? On the Performativity of Economics, Princeton University Press

CHAKRABARTI, RAJESH; WILLIAM MEGGINSON; and PRADEEP K. YADAV (2008) Corporate Governance in India, Journal of Applied Corporate Finance, Vol. 20, Issue 1, pp. 59-72

CIOFFI, JOHN and MARTIN HÖPNER (2006) The Political Paradox of Finance Capitalism: Interests, Preferences, and Center-Left Party Politics in Corporate Governance Reform, Politics \& Society, 34; 463-502 
CLARK, GORDON (2000) Pension Fund Capitalism, Oxford University Press D'COSTA, ANTHONY (2003) Uneven and Combined Development: Understanding India's Software Exports, World Development Vol. 31, No. 1, pp. 211-226

DE PAULA, GERMANO; JOÃO CARLOS FERRAZ; and MARIANA IOOTTY (2002) Economic Liberalization and changes in corporate control in Latin America, The Developing Economies, $v$. 40, n. 4

EVANS, PETER (1979) Dependent Development: The Alliance of Multinational, State, and Local Capital in Brazil, Princeton University Press

GHOSH, JAYATI (2011) The Challenge of Ensuring full employment in the twenty-first century, The Indian Journal of Labour Economics, vol 54. N. 1

GOSWAMI, OMKAR (2001), "India - The Tide Rises, Slowly", Corporate Governance in Development: The Experiences of Brazil, Chile, India, and South Africa, OECD Development Centre

GORGA, ERICA (2006) Culture and Corporate Law Reform: A Case Study of Brazil, Journal of International Economic Law, Vol. 27, No. 3 (University of Pennsylvania)

GRÜN, ROBERTO (2007) Decifra-me ou te devoro! As finanças e a sociedade brasileira, MANA Estudos de Antropologia Social, v 13, n. 2, pp. 381-410

HALL, PETER and DAVID SOSKICE (eds) (2001) Varieties of Capitalism: The Institutional Foundations of Comparative Advantage, Oxford University Press

HO, KAREN (2009) Liquidated - an ethnography of Wall Street, Durham/London: Duke University Press

JARDIM, MARIA CHAVES (2007) Entre a Solidariedade e o risco: Sindicatos e fundos de pensão em tempos de governo Lula, (Tese de Doutorado) Programa de Pós-Graduação em Ciências Sociais UFSCar

KURTZ, MARCUS and SARAH BROOKS (2008) Embedding Neoliberal Reform Latin America, World Politics, 60 (January), 231-80

LA PORTA, R.; F. LOPEZ-DE-SILANES, and A. SHLEIFER (1999). Corporate Ownership Around the World, Journal of Finance 54, 471-517

LAZZARINI, SERGIO (2011) Capitalismo de Laços: os Donos do Brasil e suas Conexões, Rio de Janeiro: Campus

MAZUMDAR, DIPAK and SANDIP SARKAR (2008) Globalization, Labor Markets and Inequality in India, Routledge

METTENHEIM, KURT VON (2010) Federal Banking in Brazil: Policies and Competitive Advantages, Pickering \& Chatto Ltd

MACKENZIE, DONALD (2006) An Engine, Not A Camera: How Financial Models Shape Markets, MIT Press

NAIB, SUDHIR (2004) Disinvestment in India - policies, procedures, practices, Sage Publications NAYAR, BALDEV (2009) The Myth of the Shrinking State - Globalization and the State in India, New Delhi: Oxford University Press

PANAGARIYA, ARVIND (2008) India: The Emerging Giant, Oxford University Press

RAJAN, RAGHURAM and LUIGI ZINGALES (2003) The great reversals: the politics of financial development in the twentieth century, Journal of Financial Economics, 69: 5-50

REED, ANANYA MUKHERJEE (2002) Corporate Governance Reforms in India, Journal of Business Ethics, 37: 249-268 
RODRIK, DANI (2004) "Industrial Policy for the Twenty-First Century", Working Paper Series rwp04-047, Harvard University, John F. Kennedy School of Government

SANTANA, CARLOS HENRIQUE (2012) “Trajetórias de reformas e mudanças institucionais na semiperiferia: abertura financeira e capacidades estatais no Brasil e Índia", (Tese de Doutorado em Ciência Política), Instituto de Estudos Sociais e Políticos da Universidade Estadual do Rio de Janeiro (IESP/UERJ)

STALLINGS, BARBARA and ROGERIO STUDART (2006) Finance for development: Latin America in comparative perspective. Washington: Brookings Institution Press/CEPAL

SCHAPIRO, MARIO (2010) Development Bank, Law and Innovation Financing in a New Brazilian Economy, The Law and Development Review, Manuscript 1045

SARKAR, JAYATI and SUBRATA SARKAR (2008) Debt and corporate governance in emerging economies: Evidence from India, Economics of Transition, Vol 16(2), 293-334

SCHNEIDER, BEN ROSS (2009a) Hierarchical Market Economies and Varieties of Capitalism in Latin America, Journal of Latin American Studies 41, 553-575

SCHNEIDER, BEN ROSS (2009b) A comparative political economy of diversified business groups, or how states organize big business, Review of International Political Economy, 16: 2, 178-201

SCHNEIDER, BEN ROSS (2008) Economic Liberalization and Corporate Governance : The Resilience of Business Groups in Latin America, Comparative Politics, vol. 40, no. 4, pp. 379-98 SOM, LALITA (2006) Stock Market Capitalization and Corporate Governance in India, Oxford University Press

STREECK, WOLFGANG (2012) Citizens as Customers - Considerations on the New Politics of Consumption, New Left Review 76, July-August

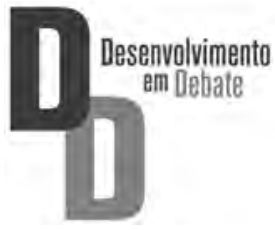

